\title{
When is an Assay of Cytomegalovirus Antigenemia Useful in Detecting Cytomegalovirus Colitis?
}

\author{
Kyeong Ok Kim \\ Department of Internal Medicine, Yeungnam University College of Medicine, Daegu, Korea
}

Cytomegalovirus (CMV) in patients with moderate-tosevere UC can worsen colitis and be associated with corticosteroid refractoriness. ${ }^{1-4}$ Early diagnosis and proper intervention is therefore very important. However, the clinical diagnosis of CMV colitis is very difficult.

The diagnosis of CMV colitis in UC patients can be confirmed by histology, which comprises either PCR or immunohistochemistry (IHC). ${ }^{5}$ However, tissue PCR for $\mathrm{CMV}$ is controversial because of the possibility for false positives. ${ }^{6}$ Although IHC staining may be the best method to confirm CMV colitis, ${ }^{7-9}$ it takes several days for this test to yield results, and could be associated with hemorrhage or perforation. ${ }^{10-12}$ Many clinicians have tried to identify the best method of diagnosing CMV colitis. With this in mind, I read the study of Chun et al. ${ }^{13}$ with great interest. They assessed the clinical utility of the CMV antigenemia assay for the diagnosis of CMV colitis and predicting the outcomes of patients with UC. According to their results, CMV colitis was more common in patients with positive CMV antigenemia (eight patients, 66.7\%), and this association was statistically significant $(P=0.001)$. The results were consistent with other similar studies, which showed low sensitivity and high specificity. ${ }^{12,14}$ They suggested 2 pp65-positive cells per 2x10 ${ }^{5}$ polymorphonuclear leukocytes as a cut-off value, and this is very meaningful.

However, among patients with positive antigenemia assay

Received February 23, 2015. Revised February 25, 2015. Accepted February 25, 2015.

Correspondence to Kyeong Ok Kim, Division of Gastroenterology and Hepatology, Department of Internal Medicine, Yeungnam University College of Medicine, 170 Hyeonchung-ro, Nam-gu, Daegu 705-703, Korea. Tel: +8253-620-3835, Fax:+82-53-623-8038, E-mail: cello7727@ naver.com

Financial support: None. Conflict of interest: None. results, three did not have CMV colitis and four with negative results had CMV colitis. In addition, ganciclovir was considered only in tissue-confirmed cases with steroid refractoriness. I am therefore curious as to whether these results have any clinical significance in the diagnosis of CMV colitis. Can the antigenemia assay substitute histologic evaluation? I believe that Chun et al. did not clearly demonstrate the significance of the CMV antigenemia assay without histology in the diagnosis of CMV colitis. Even in cases where the antigenemia assay was negative, they considered antiviral therapy if tissues showed CMV colitis. Therefore, I think we eventually need endoscopy and tissue confirmation in steroid refractory UC patients to decide upon antiviral therapy. One study suggested that the CMV antigenemia assay has a diagnostic role only in conjunction with endoscopic findings. ${ }^{14}$ I agree with this opinion; however, considering the high rate of false positive results of PCR for CMV, it could be helpful for diagnosis only when tissue PCR is positive and IHC staining is negative.

The role of CMV in the exacerbation of UC is still under debate. ${ }^{6}$ Several studies have reported that CMV reactivation could be improved without antiviral treatment, ${ }^{15,16}$ and others have suggested that in patients who are resistant to corticosteroids, antiviral therapy should be considered if they are positive for CMV in tissue studies. ${ }^{17}$ Chun et al. also demonstrated a significant association of CMV antigenemia with steroid refractoriness, and suggested early rescue therapy. ${ }^{13}$

CMV antigenemia could be a good predictor of clinical outcomes such as steroid refractoriness. However, it is limited in the diagnosis of CMV colitis. Despite these limitations, I think it could be very helpful in some cases. Therefore, we need to define the proper indication of the CMV antigenemia assay in the diagnosis of CMV colitis.

\footnotetext{
- Copyright 2015. Korean Association for the Study of Intestinal Diseases. All rights reserved.

This is an Open Access article distributed under the terms of the Creative Commons Attribution Non-Commercial License (http://creativecommons.org/licenses/by-nc/3.0)

which permits unrestricted non-commercial use, distribution, and reproduction in any medium, provided the original work is properly cited.
} 


\section{REFERENCES}

1. Cottone M, Pietrosi G, Martorana G, et al. Prevalence of cytomegalovirus infection in severe refractory ulcerative and Crohn's colitis. Am J Gastroenterol 2001;96:773-775.

2. Domenech E, Vega R, Ojanguren I, et al. Cytomegalovirus infection in ulcerative colitis: a prospective, comparative study on prevalence and diagnostic strategy. Inflamm Bowel Dis 2008;14:1373-1379.

3. Maher MM, Nassar MI. Acute cytomegalovirus infection is a risk factor in refractory and complicated inflammatory bowel disease. Dig Dis Sci 2009;54:2456-2462.

4. Papadakis KA, Tung JK, Binder SW, et al. Outcome of cytomegalovirus infections in patients with inflammatory bowel disease. Am J Gastroenterol 2001;96:2137-2142.

5. Rahier JF, Ben-Horin S, Chowers Y, et al. European evidencebased Consensus on the prevention, diagnosis and management of opportunistic infections in inflammatory bowel disease. J Crohns Colitis 2009;3:47-91.

6. Lawlor G, Moss AC. Cytomegalovirus in inflammatory bowel disease: pathogen or innocent bystander? Inflamm Bowel Dis 2010;16:1620-1627.

7. Drew WL. Diagnosis of cytomegalovirus infection. Rev Infect Dis 1988;10(Suppl 3):S468-S476.

8. Goodgame RW. Gastrointestinal cytomegalovirus disease. Ann Intern Med 1993;119:924-935.

9. Kambham N, Vij R, Cartwright CA, Longacre T. Cytomegalovirus infection in steroid-refractory ulcerative colitis: a casecontrol study. Am J Surg Pathol 2004;28:365-373.
10. Almeida N, Romaozinho JM, Amaro P, Ferreira M, Cipriano MA, Leitao MC. Fatal mid-gastrointestinal bleeding by cytomegalovirus enteritis in an immunocompetent patient. Acta Gastroenterol Belg 2009;72:245-248.

11. Frank D, Raicht RF. Intestinal perforation associated with cytomegalovirus infection in patients with acquired immune deficiency syndrome. Am J Gastroenterol 1984;79:201-205.

12. Nagata N, Kobayakawa M, Shimbo T, et al. Diagnostic value of antigenemia assay for cytomegalovirus gastrointestinal disease in immunocompromised patients. World J Gastroenterol 2011;17:1185-1191.

13. Chun J, Lee C, Kwon JE, et al. Usefulness of the cytomegalovirus antigenemia assay in patients with ulcerative colitis. Intest Res 2015;13:50-59.

14. Kim JW, Boo SJ, Ye BD, et al. Clinical utility of cytomegalovirus antigenemia assay and blood cytomegalovirus DNA PCR for cytomegaloviral colitis patients with moderate to severe ulcerative colitis. J Crohns Colitis 2014;8:693-701.

15. Matsuoka K, Iwao Y, Mori T, et al. Cytomegalovirus is frequently reactivated and disappears without antiviral agents in ulcerative colitis patients. Am J Gastroenterol 2007;102:331-337.

16. Leveque N, Brixi-Benmansour H, Reig T, et al. Low frequency of cytomegalovirus infection during exacerbations of inflammatory bowel diseases. J Med Virol 2010;82:1694-1700.

17. Roblin X, Pillet S, Oussalah A, et al. Cytomegalovirus load in inflamed intestinal tissue is predictive of resistance to immunosuppressive therapy in ulcerative colitis. Am J Gastroenterol 2011;106:2001-2008. 